\title{
Loan Loss Provisioning of the U.S. Commercial Banks after the Financial Crisis
}

\author{
Alan T. Wang ${ }^{1}$, Wen-Chung $\mathrm{Hsu}^{2}$, Wen-Cheng $\mathrm{Ho}^{2, *}$ \\ ${ }^{1}$ Department of Accountancy, Institute of Finance and Banking, National Cheng Kung University, Taiwan \\ ${ }^{2}$ Department of International Business Studies, National Chi Nan University, Taiwan
}

Copyright $(2019$ by authors, all rights reserved. Authors agree that this article remains permanently open access under the terms of the Creative Commons Attribution License 4.0 International License

\begin{abstract}
As bank managers have informational advantage in screening and monitoring borrowers, loan loss provisions determined by bank managers may contain important information for outside investors and regulators. This paper adapts a time-series framework and finds that loan loss provision contains information for future non-performing loans during the post-crisis period. This indicates that U.S. commercial banks have been associated with enhanced risk-taking discipline [Bushman and Williams, 2012]. Secondly, high yield corporate bond spreads have contained information for future bad loans, and loan loss provisioning by bank managers has incorporated such information. Finally, when exercising the discretion of loan loss provisioning by bank managers, smoothing the long-run level of loan loss reserves has been considered. Traditional hypotheses such as earnings management, capital management or income signaling are not supported by the data.
\end{abstract}

Keywords Loan Loss Reserve, Loan Loss Provision, NPL

\section{Introduction}

It is important for banks to appropriately measure the levels of bad and doubtful loans. Loan loss reserve (LLR) is the money that a bank sets aside and prepares to offset future losses on outstanding loans. At the end of each period, banks determine their probable values of loan losses and then record loan loss provisions (LLP) in the income statement. LLP is an expense which will reduce the bank's reported earnings. The offsetting credit increases the bank's LLR, which reduce the values of outstanding loans in its balance sheet. The purpose of LLP is to adjust banks' LLR to reflect expected future losses on their loans. ${ }^{1}$ However, determining the level of loan loss provision is at the discretion of the bank managers. The determination of LLR incorporates both statistical estimates and subjective assessments (Bella and McKenna, 2009). Besides, Basel II accord allowed LLR to count toward Tier II capital up to a maximum of $0.6 \%$ of risk-weighted assets. Thus, how banks determine their loan losses for each period have direct effects on their reported earnings and capital.

There has been a debate regarding the recognition of loan losses between the accounting professionals and bank regulators. The purposes of accounting standard setting are concerned with the transparency of providing information to the outsiders of the firms. In contrast, bank regulators seek to limit the frequency and cost of bank failures. From the perspective of bank regulators, LLR should serve to absorb expected loan losses while bank capitals should serve to absorb unexpected loan losses (Laeven and Majnoni, 2003; Bikker and Metzemakers, 2005). The methodology to recognize loan losses set forth by the Financial Accounting Standards Board (FASB) and International Accounting Standards Board (IASB) is referred to as the incurred loss model. In the United States, Financial Accounting Standard (FAS) Statement 5 provides for accrual of losses by a charge to income statement based on estimated losses if two conditions are met: (1) information available prior to the issuance of the financial statements indicates that it is probable that an asset has been impaired, and (2) the amount of loss can be reasonably estimated. FAS allows for the use of loss history in impairment analysis. Balla and McKenna (2009) argue that current incurred loss models set by accounting standards cannot incorporate information from expected future changes into economic variables that affect credit defaults. The incurred loss model has been argued to cause the financial crisis of 2007-2009 because of its pro-cyclical

1 Current LLR is equal to LLR from the previous period plus LLP minus net charge-off. 
nature: when the economy is in expansion, banks tend have less provisions for bad loans and thus report higher earnings. However, in periods of economic downturns, banks tend to increase bad loans provisions and thus report lower earnings, which subsequently further the credit crunch due to capital inadequacy. (Laeven and Majnoni, 2003; Bouvatier and Lepetit, 2008).

It is argued that dynamic provisioning offers a better tradeoff between the goals of bank regulators and the accounting profession than the incurred loss model (Balla and McKenna, 2009). Dynamic provisioning uses statistical methods based on historical data for various asset classes to determine the level in addition to any other provisions that are event driven on a quarterly basis. The major purpose of dynamic provisioning is to increase reserves during good economic times to be used to absorb losses incurred during economic downturns. As a result, dynamic provisioning is also known as counter-cyclical provisioning. The Basel III accord also explicitly addresses countercyclical capital buffers (Balla, Rose, and Romero, 2012). If expected losses are greater than the LLR, regulatory capital ratio overstates the bank capital available to absorb future losses. However, extra reserves also cause the problems of earnings management, which is undesirable by the accounting profession. Using LLR to manage reported earnings is in conflict with the goals of transparency of a bank's balance sheet. Even if banks want to build extra LLR during good economic times, the accounting guidelines pose a constraint.

For public held banks, the SEC's attitude also plays an important role for bank managers to determine the appropriate level of LLR (Bella, Rose, and Romero, 2012). In 1997, the SEC expressed concerns that U.S. banks overstated their LLR, and in 1998, the SEC required SunTrust Bank to restate its earnings and lower its loan loss reserves by $\$ 100$ million. Bella, Rose, and Romero (2012) argue that the SEC's action reflected a strengthening of accounting priorities. For example, Bella and Rose (2011) found that in the years prior to the SunTrust restatement, the level of LLR for publicly held banks was on average 20.9 percent higher than the level of privately held banks. After 1998, the level of LLR at publicly held banks fell to only 9.5 percent higher. Besides, quarterly LLP were on average 47 percent higher at publicly held banks before the SunTrust restatement, and then became 35 percent higher afterwards.

While increased accounting discretion for LLP may facilitate incorporation of more information about future expected losses and mitigate pro-cyclicality, it also increases the potential for opportunistic accounting behavior by managers that can impair bank transparency and lead to unfavorable consequences. Bushman and Williams (2012) investigated the implications of loan loss provisioning for banks' risk-taking behaviors. They developed two measures of forward-looking provisioning practices and investigated how these provisioning practices related to bank's risk-taking behaviors: one measured the relation between LLP and contemporaneous earnings (income smoothing), the other measured the relation between LLP and future change in non-performing loans (NPL). ${ }^{2}$ The conclusion is that forward-looking provisioning designed to smooth earnings dampens discipline over risk-taking, but forward-looking provisioning reflecting timely recognition of expected future loan losses is associated with enhanced risk-taking discipline. $^{3}$

After the onset of the global financial crisis, changes in the U.S. financial regulations were called for. The U.S. Congress has passed new laws such as the Dodd-Frank Wall Street Reform and Consumer Protection Act of 2010, and banks have since been under more stringent scrutiny. Since the determination of LLP is at bank managers' discretion, the purpose of this study is to investigate what relevant information is contained in the level of LLP in the post-financial crisis period. In particular, we are concerned with if bank managers have incorporated information for future bad loans given their informational advantage. For example, we try to answer the following questions: how are these reserves related to past and current loan losses? What other information is incorporated in the LLP? Following Beatty and Liao (2011) and Bushman and Williams (2012), do these LLP contain predictive information for future loan losses such as NPL? Does the corporate bond market contain information for LLP determination?

This study helps distinguish between earnings management and bank managers' rational expectations for expected future loan losses in the post-financial crisis period. A positive relation between earnings and LLP (Collins, Shackelford, and Wahlen, 1995; Wall and Koch, 2000; Laeven and Majnoni, 2003) may not necessarily be evidence of earnings management. Bank managers may foresee an increase in future loan loss and increase current level of LLR when banks' earnings are high, leading to a positive relation between earnings and LLP. Based on information asymmetry hypothesis, it is likely that bank managers increase LLP when banks' earnings are high is not necessarily for earnings management purpose.

This paper contributes to literature in several ways. First, we adopt a time series model to analytically describe the information content in loan losses in which bank managers have superior information for future loan losses. When bank managers determine the level of LLP, they incorporate the historical loan loss information as well as future loan loss foreseen by themselves. We find that, LLP is positively related to future bad loans. LLP does contain

2 One approach measures relations between provisioning and changes in asset volatility and bank leverage. The other approach measures relations between provisioning and bank risk-shifting. Risk-shifting occurs when bank increase the value of the option (Merton, 1977), which is equivalent to deposit insurance, without internalizing the full cost of the increased insurance.

3 It is argued in banking literature that smoothing is implicitly forward-looking and can mitigate pro-cyclicality. Gambera (2000) and Beatty and Liao (2011) show that current economic conditions have predictive power for future NPL. 
information for future NPL after controlling the current level of NPL. Earnings management and capital management of LLP for U.S. commercial banks disappear. This is also evidence strengthening the incurred loss model in LLP for U.S. commercial banks in the post-crisis period.

Secondly, we provide evidences that the information of default yield spread observed in the high yield bond market helps predict NPL and LLP. Because corporate bond yield spread reflects the default risk of the bond over the bond's life (Longstaff and Schwartz, 1995), bond default risk can be related to loan default risk in the future given that they both are related to economic conditions. Although the relation between bond spread and loan spread has been documented, how LLP and NPL are related to bond spread has not been investigated. ${ }^{4}$

Finally, it has been argued that bank managers could attempt to obscure income-smoothing behavior by trying to minimize fluctuations in LLR to avoid regulatory and market scrutiny. This could be achieved through exercising discretion over loan charge-offs, For example, by accelerating charge-offs to offset higher loan loss provisions to keep loan loss reserves unchanged. We find that net charge-offs are not used to smooth LLR during this post-crisis period for U.S. commercial banks. From the perspective of time series analysis, we show that LLR is approximately governed by a mean-reverting process. We find when LLR is above (below) its mean in the last period, LLP tends to decrease (increase). This phenomenon indicates that when bank managers recognize LLP, they have considered the relative level of LLR to smooth the fluctuations in LLR in the long run regardless of income-smoothing behavior.

The rest of this paper is structured as follows: In Section 2 we describe the related literature. An analytical framework for information transmission process between LLP and NPL is given in Section 3. In Section 4 data is described. Section 5 discusses results of various models under considerations. Finally, Section 5 concludes.

\section{Literature Review}

Documents that bank managers have incentives to use LLP to manage earnings. Bank managers can increase LLP in good times and decrease in bad times to smooth a bank's earnings and, in turn, to increase the bank's stock price. The results of this income-smoothing hypothesis are mixed in the literature. Collins, Shackelford, and Wahlen (1995) and Greenawalt and Sinkey (1988) find a positive relation between LLP and earnings, supporting the earnings management hypothesis. Wall and Koch (2000) also offer a review of empirical evidences on loan loss accounting. They conclude that banks do use LLR to manage reported

4 For example, the explanatory power of CDS and bond spreads for bank loan spread have been documented by Norden and Wagner (2008). earnings and capital. Others such as Liu and Ryan (2006) also conclude the evidence of income smoothing over a prolonged period. Using yearly bank data of 40 countries from 1995 to 2002, However, Beatty, Chamberlain and Magliolo (1995) and Ahmed, Takeda, and Thomas (1999) do not find evidence of earnings management. Fonseca and Gonzalez (2008) conclude that investor protection and legal enforcement reduce banks' incentives to smooth earnings. Incentives to smooth earnings decline with accounting disclosure, restrictions on bank activities, and official and private supervision.

Hasan and Wall (2004) consider fundamental (nondiscretionary) determinants of the allowance, such as NPL, and discretionary determinants, such as income before the loan loss provision for all samples of U.S. banks and non-U.S. banks. They conclude that the loan loss allowance is sensitive to provision income in all countries, but some other fundamental variables such as loan charge-off ratio and loan-to-asset ratio are not significant for non-U.S. banks. Laeven and Majnoni (2003) also find that the evidence from international data support the income-smoothing hypothesis.

Executive compensations also provide incentives for earnings management. For example, Cornett et al. (2008) examine the impact of incentive-based compensation on the performance of large U.S. bank holding companies in light of potential earnings management for the period of 1994 to 2002. They find that incentive-based compensation has a significant impact on financial performance as measured by reported earnings. However, once earnings are adjusted for discretionary accruals, the link between compensation and performance disappears.

It is also documented that bank managers use LLP to manage regulatory capital as well as to signal private information about future earnings (Ahmed, Takeda and Thomas, 1999). Because LLR count as part of capital, if a bank has relatively lower level of capital, the bank managers have an incentive to increase LLP. ${ }^{5}$ Laeven and Majnoni (2003) address the issue of loan loss provisioning as an integral component of capital regulation. They argue that bank capital should be related to the size of unexpected credit losses and LLR to the size of expected losses. Moyer (1990) and Beatty, Chamberlain and Magliolo (1995) find evidence of a negative relation between LLP and capital ratios, consistent with the use of LLP to avoid violating capital requirement in the future. Bikker and Metzemakers (2005) also find supporting evidence for capital management hypothesis. However, Collins, Shackelford, and Wahlen (1995) do not find evidence of capital management.

Some literature investigates if changes in LLP have explanatory power for future earnings (signaling

5 LLR is part of primary capital before 1990, but after Basel I accord, LLR is considered as part of supplementary capital and is limited to $1.25 \%$ of risk-weighted assets. The limit has been reduced to $0.6 \%$ in Basel II accord. 
hypothesis). Beaver et al. (1989) suggest that investors interpret an increase in LLP as a sign of strength. Wahlen (1994) documents a positive relation between unexpected LLP and future pre-loan loss earnings changes and stock returns. Beaver and Engel (1996) also find evidence supporting the signaling hypothesis. Ahmed, Takeda and Thomas (1999) consider the effect of new capital regime in 1990 and conclude that capital management is present, but their results do not support the earnings management or signaling hypothesis.

Literature also has documented the relation between loan rate and bond rate. Angbazo, Mei and Saunders (1998) conclude corporate bond spread has a positive effect on highly leveraged transaction (HLT) syndicated loans and conclude these two markets are not fully integrated. Thomas and Wang (2004) also investigate the integration of intermediated and disintermediated financial markets through HLT syndicated loans during the 1990s. HLT loan market's spreads are strongly affected by bank liquidity initially, but, from 1994-1999, junk bond market liquidity factors affect bank loan pricing. Norden and Wagner (2008) find that changes in CDS spreads have a significantly positive coefficient and explain about $25 \%$ of subsequent monthly changes in aggregate loan spreads during 2000-2005. In particular, CDS spreads explain loan rates much better than same rated bonds. These findings indicate loan market and bond market are getting more integrated over time.

\section{Information Transmission between LLP and NPL}

Because loan loss reserves is the money to set aside to offset future loan losses, the adequacy of loan loss reserves to cover loan losses is generally measured against the level of NPL. NPL are those delinquent by being 90 or more days past due or in non-accrual status. Balla and McKenna (2009) use the data from Call Reports and find that at any point of time between 1992 and 2006, there were more reserves than there were NPL. However, since 2007, the year of subprime mortgage crisis, the level of NPL started to exceed the level of LLR. Furthermore, they also demonstrate that modifications in LLR tend to lag changes in NPL. That is, LLR increase more slowly than NPL during economic downturns and fall more slowly in booms. Laeven and Majnoni (2003) also find evidence that many banks around the world delay provisioning for bad loans until too late, magnifying the impact of the economic cycle on banks' income and capital.

This study applies a simple time-series model, in which there is information asymmetry between bank managers and outsiders (such as supervisors and investors), to examine information transmission between LLP and NPL. Loan loss provisioning may contain information about future loan default risk if bank managers have rational expectations for future bad loans. It is likely that some loan loss provisioning may be an information event, while others may be not. If it is an information event under information asymmetry, it will be related to the future change in NPL. Even though bank managers and outsiders observe the past and current levels of NPL, outsiders may not recover all the information that bank managers have in determining the new level of LLR.

A time-series theorem in Fuller (1976) states that any time series process has both invertible and non-invertible representations. Following Jiang and Lee (2013), although NPL may be governed by a general ARMA process, for expositional simplicity, this study assumes that outsiders observe current and past NPL and infer a first-order moving average, $\mathrm{MA}(1)$, process: ${ }^{6}$

$$
N P L_{t}=(1-\lambda L) u_{t},|\lambda|<1.0,
$$

where $N P L_{t}$ is the NPL at time $t, L$ is the lag operator, and $u_{t}$ is white noise with variance $\operatorname{Var}\left(\mathrm{u}_{\mathrm{t}}\right)=\sigma_{\mathrm{u}}^{2}$, the autocorrelation functions (ACFs) for this reserves process are

$$
\begin{aligned}
\operatorname{var}\left(\mathrm{NPL}_{\mathrm{t}}\right)= & \left(1+\lambda^{2}\right) \sigma_{\mathrm{u}}^{2}, \operatorname{cov}\left(\mathrm{NPL}_{\mathrm{t}}, \mathrm{NPL}_{\mathrm{t}-1}\right)=-\lambda \sigma_{\mathrm{u}}^{2}, \\
& \operatorname{cov}\left(\mathrm{NPL}_{\mathrm{t}}, \mathrm{NPL}_{\mathrm{t}-\mathrm{k}}\right)=0 \text { for } \mathrm{k} \geq 2
\end{aligned}
$$

Suppose that managers, given the past and current levels of NPL, infer the following MA(1) process of NPL:

$$
\mathrm{NPL}_{\mathrm{t}}=\left(1-\lambda^{-1} \mathrm{~L}\right) \mathrm{v}_{\mathrm{t}}
$$

where $v_{t}$ is white noise with variance $\operatorname{Var}\left(v_{t}\right)=\sigma_{v}^{2}$, the ACFs for NPL process are

$$
\begin{gathered}
\operatorname{var}\left(N P L_{t}\right)=\left(1+\lambda^{-2}\right) \sigma_{v}^{2}, \operatorname{cov}\left(N P L_{t}, N P L_{t-1}\right)= \\
-\lambda^{-1} \sigma_{v}^{2}, \\
\operatorname{cov}\left(N P L_{t}, N P L_{t-k}\right)=0, \text { for } k \geq 2 .
\end{gathered}
$$

If $\sigma_{v}^{2}$ is set to equal to $\lambda^{2} \sigma_{u}^{2}$, then the ACFs in (2) and (4) are identical, which implies that the processes governing NPL given by (1) and (3) are identical.

Because $\sigma_{v}^{2}=\lambda^{2} \sigma_{u}^{2}$, and $|\lambda|<1.0, \sigma_{v}^{2}$ is smaller than $\sigma_{u}^{2}$. The meaning underlying the inequality is that the one-step forecast error of the $N P L_{t}$ process inferred by bank managers is smaller than that inferred by outsiders. This is intuitive because the information set available to bank managers is larger than that available to outsiders.

Alternatively, the MA(1) processes of $N P L_{t}$ inferred by both outsiders and bank managers ((1) and (3)) have autoregressive representations:

$$
\begin{gathered}
u_{i}=(1-\lambda L)^{-1} N P L_{t}=\sum_{j=0}^{\infty} \lambda^{j} N P L_{t-j}, \\
v_{t}=\left(1-\lambda^{-1} L\right)^{-1} N P L_{t}= \\
-\left(\lambda L^{-1}\right)\left(1-\lambda L^{-1}\right)^{-1} N P L_{t}=-\sum_{j=1}^{\infty} \lambda^{j} N P L_{t+j} . \quad(5)
\end{gathered}
$$

The innovations in outsiders' $N P L_{t},\left\{u_{i}\right\}$, are backward-looking, while the innovations in bank managers' $N P L_{t},\left\{v_{i}\right\}$, are forward-looking.

6 This framework of analysis is adapted from Jiang and Lee (2013). We assume NPL and LLP are stationary for expositional purpose for simplicity. In empirical analysis we estimate the models with variables in level as well as in difference. 
The bank managers have an informational advantage than outsiders by observing $v_{i}$, and they can take this advantage in their loan loss provisioning decisions. In this case, changes in LLP will be a function of the innovation $v_{i}$ that they observe (outsiders do not):

$$
\begin{array}{r}
L L P_{t}=f\left(v_{t}\right)=\sum_{i=0}^{\infty}\left(\theta_{i} L^{i}\right) v_{t}= \\
\sum_{i=0}^{\infty} \theta_{i} v_{t-i}, \text { with } \sum_{i=0}^{\infty} \theta_{i}^{2}<\infty,
\end{array}
$$

where $\theta$ is a constant.

By using (5) into (6), we can get:

$$
\begin{aligned}
& L L P_{t}=\sum_{i=0}^{\infty}\left(\theta_{i} L^{i}\right) v_{t}=\sum_{i=0}^{\infty}\left(\theta_{i} L^{i}\right)\left\{\left(1-\lambda^{-1} L\right)^{-1} N P L_{t}\right\}= \\
& =\sum_{i=0}^{\infty}\left(\theta_{i} L^{i}\right)\left(-\sum_{j=1}^{\infty} \lambda^{j} N P L_{t+j}\right)=-\sum_{j=-\infty}^{\infty} \delta_{j} N P L_{t-j},
\end{aligned}
$$

where $\delta_{j}$ for $\mathrm{j}=-\infty, \cdots,-2,-1,0,1,2, \cdots, \infty$ is a function of $\theta_{i}$ and $\lambda^{j}$. That is, change in LLP will be a linear combination of future, current, and past changes in NPL. In practice, bank managers do not have perfect foresights and thus (7) will be:

$$
L L P_{t}=-\sum_{j=0}^{\infty} \delta_{j} N P L_{t-j}+E_{t}\left[-\sum_{j=-\infty}^{-1} \delta_{j} N P L_{t-j}\right] .
$$

In contrast, suppose that bank managers do not have any informational advantage or that they do not make loan loss provisioning decisions based on their informational advantage. Then the change in LLP will be a function of the innovations, $u_{t}$, that outsiders observe:

$$
\begin{aligned}
& \Delta \mathrm{E}_{\mathrm{t}}=\mathrm{f}\left(\mathrm{u}_{\mathrm{t}}\right)=\sum_{\mathrm{i}=0}^{\infty}\left(\theta_{\mathrm{i}} \mathrm{L}^{\mathrm{i}}\right) \mathrm{u}_{\mathrm{t}}= \\
& \sum_{\mathrm{i}=0}^{\infty} \theta_{\mathrm{i}} \mathrm{u}_{\mathrm{t}-1}, \text { with } \sum_{\mathrm{i}=0}^{\infty} \theta_{\mathrm{i}}^{2}<\infty .
\end{aligned}
$$

Then by using $u_{t}$ in (5), change in LLP and change in NPL processes will be related as follows:

$$
\begin{gathered}
L L P_{t}=\sum_{i=0}^{\infty}\left(\theta_{i} L^{i}\right) u_{t}=\sum_{i=0}^{\infty}\left(\theta_{i} L^{i}\right)(1-\lambda L)^{-1} N P L_{t}= \\
\sum_{i=0}^{\infty}\left(\theta_{i} L^{i}\right)\left\{\sum_{j=0}^{\infty} \lambda^{j} N P L_{t-j}\right\}=\sum_{k=0}^{\infty} \delta_{k} N P L_{t-k},
\end{gathered}
$$

where $\delta_{k}$ for $\mathrm{k}=0,1,2, \cdots, \infty$ is a function of $\theta_{i}$ and $\lambda^{j}$. That is, a change in LLP will only reflect past and current changes in NPL and will not be related to future changes in NPL. Equivalently, they will be backward-looking.

That is, under information asymmetry, informative loan loss provisioning will be related to not only past and present changes in NPL but also future changes in NPL. However, in the absence of information asymmetry, non-informative loan loss provisioning will not be related to future changes in NPL.

It is important to distinguish between the informative and non-informative loan loss provisioning. If LLP contains new information about future NPL, it will not only be related to past and current NPL but also related to future changes in NPL. The equivalence of the two-sided regression in (8) with Granger-causality has been established by Sims (1972, theorem 2). We can thus test whether changes in LLP are informative by using the following proposition.

Proposition 1: Consider the following two-sided regression:

$$
\mathrm{LLP}_{\mathrm{t}}=\alpha+\sum_{\mathrm{j}=-\mathrm{m}}^{\mathrm{m}} \delta_{\mathrm{j}} \mathrm{NPL}_{\mathrm{t}-\mathrm{j}}+\varepsilon_{\mathrm{t}},
$$

where

$$
E\left(\varepsilon_{t}, N P L_{t-j}\right)=0 \quad \text { for }
$$
$j=-m, \cdots,-1,0,1, \cdots, m$. If the null hypothesis that all the coefficients of future NPL are zero is rejected, then $L L P_{t} \quad$ Granger-causes $N P L_{t}$. Equivalently, this Granger-causality can be tested by the null hypothesis that $\gamma_{j}=0$ for all $j>0$ based on the following regression:

$$
N L_{t}=\alpha+\sum_{j=1}^{m} \beta_{j} N L_{t-j}+\sum_{j=1}^{m} \gamma_{j} L_{L P}-j+\eta_{t} .
$$

That is, we can use the Granger-causality test as a mean of testing the predictability of LLP for future NPL, and the finding of the predictive power of LLP can be interpreted based on information asymmetry.

Although (12) is a time-series model, this study considers the case for banks over a time period, and thus (12) is generalized to panel-data settings. Furthermore, to control for other variables including GDP growth rate, earnings before tax and provisions, loan size, and corporate yield spread into (12), the base equation characterized as follows: ${ }^{7}$

$$
\begin{gathered}
\mathrm{NPL}_{\mathrm{i}, \mathrm{t}}=\alpha+\sum_{\mathrm{j}=1}^{\mathrm{m}} \beta_{\mathrm{j}} \mathrm{NPL}_{\mathrm{i}, \mathrm{t}-\mathrm{j}}+\sum_{\mathrm{j}=1}^{\mathrm{m}} \gamma_{\mathrm{j}} \mathrm{LLP}_{\mathrm{i}, \mathrm{t}-\mathrm{j}}+ \\
\text { Control variables. }
\end{gathered}
$$

\section{Data and Empirical Results}

\subsection{Data}

This study uses quarterly data of U.S. commercial banks from 2009:Q1 to 2012:Q2. The bank-related data are collected from Bankscope. After eliminating the banks not active by the end of the sample period or with too many missing values, we are left with 215 banks. As a result, we have 2,975 bank-quarter observations.

Loan default risk should be related to business cycle. More firms will default on loans and bonds during the periods of economic downturns. How default probability and bond defaults are related through the business cycle has been documented. For example, Nickell, Perraudin and Varotto (2000) and Bangia et al. (2002) use bond market data and find rating transition matrices vary across business cycle. Provisioning is procyclical because of increases in loan level during a boom, or because of the income-smoothing hypothesis. This issue of relating provisioning and procyclicality in the literature includes Greenawalt and Sinkey (1998) and Bikker and Metzemakers (2005), among others. To incorporate this macroeconomic environment factors into our analysis, we include GDP and corporate default yield spread in our analysis. We use the spread between Barclay's capital

7 Unlike our specification here, Bushman and Williams (2012) regresses LLP on future change in NPL along with other variables. 
Caa-rated yield and the U.S. 10-year treasury yield to represent default yield spread. These data are collected from Datastream. The definitions of bank variables are given in Appendix A.

Table 1. Correlation coefficients

\begin{tabular}{|c|c|c|c|c|c|}
\hline & GL & LLP & NPL & NPL/GL & EBTP \\
\hline GL & 1 & & & & \\
\hline LLP & 0.699 & 1 & & & \\
\hline NPL & 0.849 & 0.764 & 1 & & \\
\hline NPL/GL & -0.055 & 0.0147 & 0.147 & 1 & \\
\hline EBTP & 0.813 & 0.327 & 0.578 & -0.068 & 1 \\
\hline
\end{tabular}

Notes: GL, LLP, NPL, NPL/GL and EBTP represent gross loan, loan loss provision, non-performing loan, non-performing loan/total loan and earnings before tax and provisions. The sample is the quarterly data of 215 U.S. commercial banks from 2009:Q1 to 2012:Q2.

Table 1 reports the correlation coefficients between the bank variables. First, we can see gross loan is positively related to LLP, NPL, and earnings. This suggests that as loans become larger, NPL becomes larger accordingly. At the same time, earnings are also positively related to loan size. However, as loan size becomes larger, the proportion of NPL in gross loans becomes smaller. Second, LLP is positively related to current NPL and earnings. Although the correlation coefficient between LLP and earnings is positive, the size is not large. Finally, although NPL and earnings have a positive correlation coefficient, the correlation coefficient between the proportion of NPL in gross loans and earnings is negative, suggesting as the bank's earnings becomes better due to better loan markets, the size of NPL relative to loans becomes smaller.
Corporate debt spread is documented to contain information such as default probability, recovery rate, equity market risk and tax effect (for example, Longstaff and Schwartz, 1995; Elton et al., 2001). It is likely that corporate bond spread contains future default risk for loans as well. We first examine if LLP of the U.S. commercial banks at the aggregate level is positively associated with corporate bond spread observed in the past. Figure 1a and Figure $1 \mathrm{~b}$ report the cross-correlogram between the average of LLP for all for all the banks in our sample and Caa spread. Cross-correlogram measures the correlation coefficients between two variables observed in different time periods. Figure 1a illustrates the correlation coefficients between the current average of LLP for all banks and lagged Caa spreads. Similarly, Figure $1 \mathrm{~b}$ illustrates the correlation coefficients between the current average of LLP for all banks and future Caa spreads. If we consider the critical values with d.f. of 12 , the first and second orders of lags of Caa spread are positively and significantly associated with current average of LLP by observing the cross-correlogram in Figure 1a. But in the case of the association between current average of LLP and future Caa spreads, there is no significant result observed from Figure $1 \mathrm{~b}$ when the two variables are not observed in the same period. Although the length of the time series is limited, these preliminary findings are an indication of predictive power of bond market information for future LLP at the aggregate level.

The correlation coefficient between $\overline{\operatorname{LLP}}(t)$ observed at time $t$ and Caa spread observed at time $t-i, i=0,1,2, \ldots, 6$. $\overline{\operatorname{LLP}}(t)$ is the average of LLP for all the banks in our sample at time $t$.

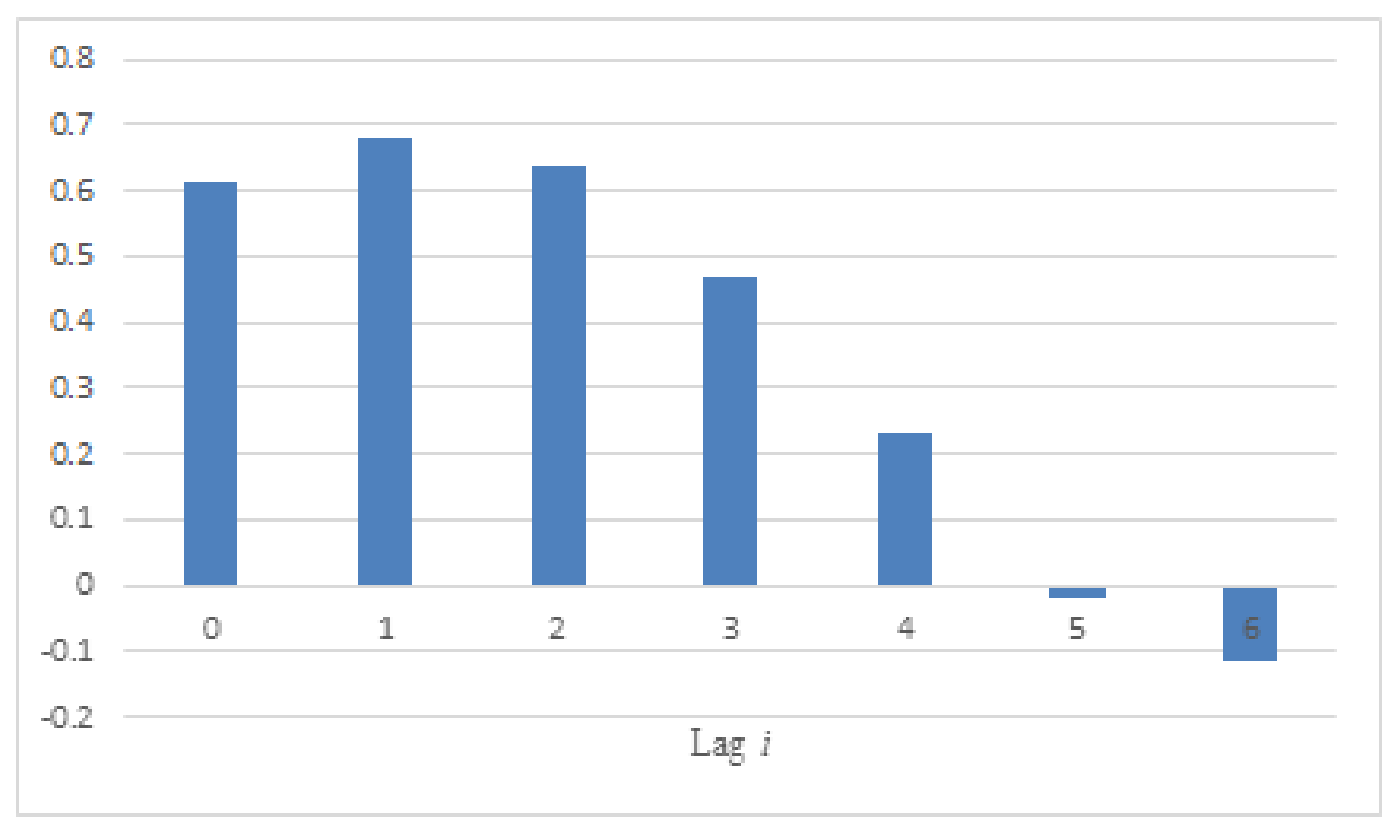

Figure 1a. Cross-correlogram: $\overline{L L P}(t)$ and Caa spread $(t-i)$ 


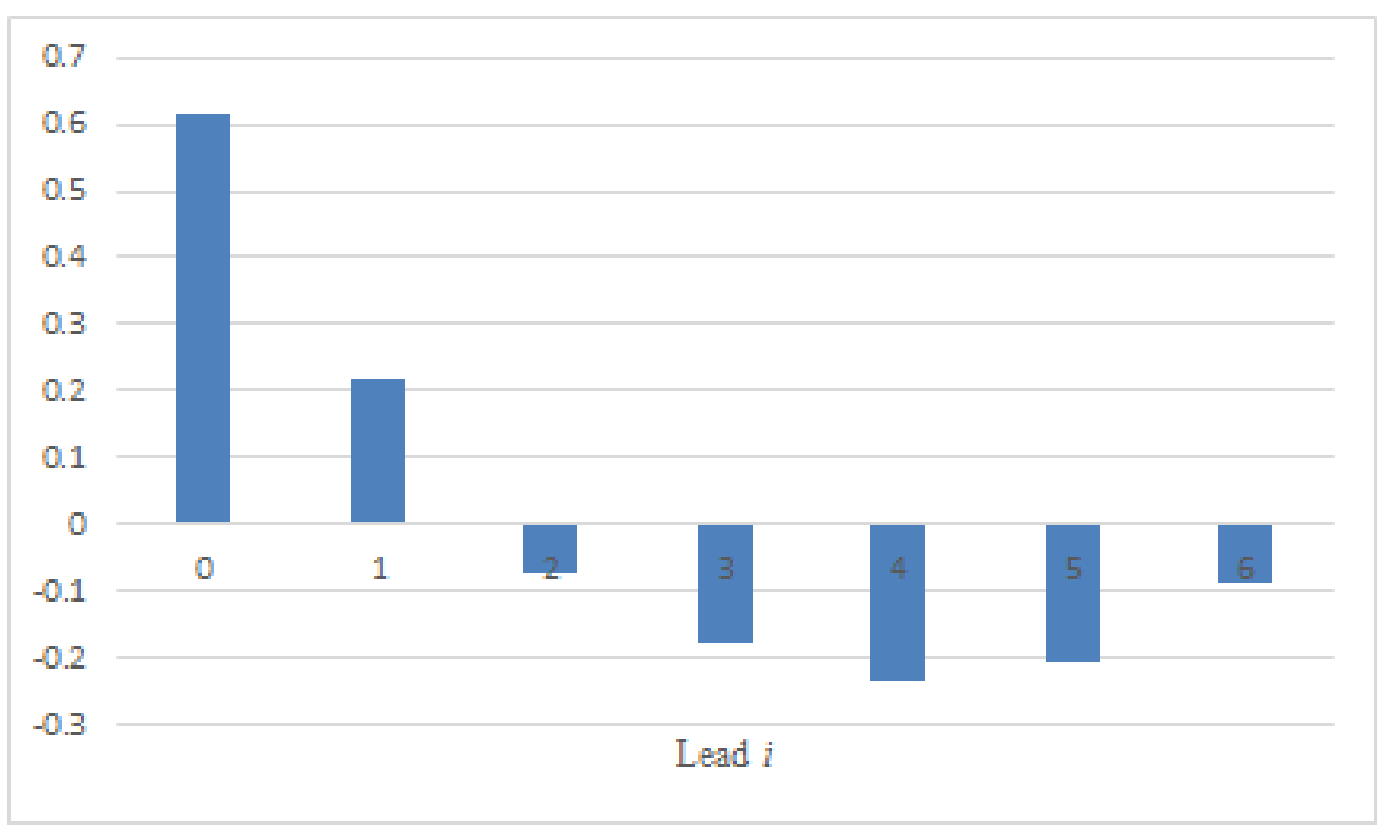

Figure 1b. Cross-correlogram: $\overline{\mathrm{LLP}}(\mathrm{t})$ and Caa spread $(t+i)$

The correlation coefficient between $\overline{\operatorname{LLP}}(t)$ observed at time $t$ and Caa spread observed at time $t+i, i=0,1,2, \ldots, 6$. $\overline{\operatorname{LLP}}(t)$ is the average of LLP for all the banks in our sample at time $t$.

\section{Empirical Results}

\subsection{LLP Determination}

We first estimate the fixed effect models of LLP to show how LLP is determined based on the potential factors we have considered. The advantage of fixed effect model is that it considers the potential differences in bank characteristics which are omitted in the regressions. The results are reported in table 2. Model 1 to Model 5 are simple regressions for each independent variable and Model 6 is the multiple regression of LLP on all independent variables from the previous five models. It can be easily observed that current LLP is mainly determined by its value from last quarter. ${ }^{8}$ Contemporaneous NPL has a positive and significant effect on LLP. This indicates that current level of NPL, which is a non-discretionary item, will affect LLP determination by bank managers. Economic conditions also affect LLP determination. Quarterly growth rate in GDP and EBTP have negative effects on LLP. When the economic condition is in the downturn, bank managers will provision more bad loans. When the economic condition is in expansion, bank

8 We also have tested whether the effect of loan size on LLP determination is present. When loan size is incorporated in the analysis, it has no effect on LLP either in simple regression or in the full model of multiple regression (not reported here). managers will provision less. The negative association between EBTP and LLP also helps clarify the income-smoothing hypothesis for U.S. commercial banks after financial crisis. Negative signs for EBTP either in Model 3 or Model 6 indicate that bank managers set more money aside when the earnings are bad, inconsistent with the earnings management hypothesis. This means that LLP determinations for the U.S. banks are more in line with the incurred loss model preferred by the accounting professions. ${ }^{9}$ Capital has a negative but no significant effect on LLP, either in Model 4 or in Model 6. This indicates the phenomenon of capital management is not observed for the U.S. commercial banks in the post-crisis period. Capital management hypothesis is thus not supported with our sample.

A positive and significant association between Caa-Treasury bond yield spread and LLP indicate that when bank managers determine LLP, they have considered the information implicit in the credit spread observed in the corporate bond market. As aforementioned, corporate bond credit spread reflects the information including default probability, and a larger credit spread is associated with a larger default probability, which is negatively associated with economic condition. Thus a positive coefficient for Caa-Treasury bond yield spread is consistent with our expectation. Comparing the results in Model 6 with those observed in the previous five models, we can find that GDP growth rate becomes insignificant. This is probably because EBTP and Caa-Treasury bond yield spread have captured the cyclical effect, and the incremental explanatory power of GDP growth becomes limited.

9 As aforementioned, Bella, Rose, and Romero (2012) argue that the SEC's action reflected a strengthening of accounting priorities. 
Table 2. Loan loss provision determination

\begin{tabular}{|c|c|c|c|c|c|c|}
\hline \multirow[b]{2}{*}{ Model } & \multicolumn{6}{|c|}{ LLP } \\
\hline & 1 & 2 & 3 & 4 & 5 & 6 \\
\hline Constant & $\begin{array}{c}5349.641 \\
(0.77)\end{array}$ & $\begin{array}{c}34595.8 \\
(4.59)^{* * *}\end{array}$ & $\begin{array}{c}47,585.76 \\
(10.80)^{* * *} \\
\end{array}$ & $\begin{array}{c}31,568.98 \\
(2.08)^{* *}\end{array}$ & $\begin{array}{c}-15,894.82 \\
(-1.73)^{*}\end{array}$ & $\begin{array}{c}-4,930.426 \\
(-0.22)\end{array}$ \\
\hline $\operatorname{LLP}(-1)$ & $\begin{array}{l}0.7503442 \\
(56.21)^{* * *}\end{array}$ & $\begin{array}{c}0.7564922 \\
(59.65)^{* * *}\end{array}$ & $\begin{array}{c}0.6614543 \\
(47.22)^{* * *}\end{array}$ & $\begin{array}{c}0.7588681 \\
(59.92)^{* * *}\end{array}$ & $\begin{array}{c}0.7553731 \\
(59.67)^{* * *}\end{array}$ & $\begin{array}{c}0.622234 \\
(41.06)^{* * *}\end{array}$ \\
\hline NPL & $\begin{array}{c}0.0186507 \\
(2.07)^{* *}\end{array}$ & & & & & $\begin{array}{c}0.0552439 \\
(6.20)^{* * *}\end{array}$ \\
\hline$\Delta \mathrm{GDP}$ & & $\begin{array}{c}-125.624 \\
(-2.74)^{* * * *}\end{array}$ & & & & $\begin{array}{c}-27.51369 \\
(-0.51) \\
\end{array}$ \\
\hline EBTP & & & $\begin{array}{l}-0.0935877 \\
(-14.18)^{* * *}\end{array}$ & & & $\begin{array}{l}-0.1025256 \\
(-15.16)^{* * *}\end{array}$ \\
\hline Capital & & & & $\begin{array}{c}-867.8318 \\
(-0.99)\end{array}$ & & $\begin{array}{c}-122.1815 \\
(-0.14)\end{array}$ \\
\hline Caa_Spread & & & & & $\begin{array}{l}338,539.4 \\
(3.98)^{* * *}\end{array}$ & $\begin{array}{l}272,048.6 \\
(2.72)^{* * *}\end{array}$ \\
\hline Obs. & 2,795 & 2,795 & 2,795 & 2,795 & 2,795 & 2,795 \\
\hline Banks & 215 & 215 & 215 & 215 & 215 & 215 \\
\hline Within group $\bar{R}^{2}$ & $58.31 \%$ & $58.36 \%$ & $61.26 \%$ & $58.25 \%$ & $58.49 \%$ & $61.99 \%$ \\
\hline Overall $\bar{R}^{2}$ & $86.18 \%$ & $85.80 \%$ & $79.01 \%$ & $85.75 \%$ & $85.83 \%$ & $86.29 \%$ \\
\hline Fixed Effect & Yes & Yes & Yes & Yes & Yes & Yes \\
\hline
\end{tabular}

Notes: LLP, NPL, $\triangle$ GDP, EBTP, Capital and Caa_Spread represent loan loss provision, non-performing loan, GDP growth rate, earnings before tax and provision, Tier I regulatory capital ratio (\%) and credit spread. Numbers in parentheses are $t$-statistics. ***, **, * represent significant at $1 \%, 5 \%$ and $10 \%$ significance levels, respectively.

Table 3. Predicting NPL by loan loss provision

\begin{tabular}{|c|c|c|c|c|c|}
\hline & \multicolumn{5}{|c|}{ NPL } \\
\hline Model & 1 & 2 & 3 & 4 & 5 \\
\hline Constant & $\begin{array}{l}-3,050,328 \\
(-5.71)^{* * *}\end{array}$ & $\begin{array}{l}-3,048,024 \\
(-5.74)^{* * *}\end{array}$ & $\begin{array}{l}-3,076,036 \\
(-5.80)^{* * *}\end{array}$ & $\begin{array}{l}-3,068,234 \\
(-5.79)^{* * *}\end{array}$ & $\begin{array}{c}-2790144 \\
(-5.46)^{* * *}\end{array}$ \\
\hline NPL(-1) & $\begin{array}{l}0.5457324 \\
(43.51)^{* * *}\end{array}$ & $\begin{array}{l}0.5474732 \\
(43.76)^{* * *}\end{array}$ & $\begin{array}{l}0.5477352 \\
(43.97)^{* * *}\end{array}$ & $\begin{array}{l}0.5452012 \\
(43.75)^{* * *}\end{array}$ & $\begin{array}{l}0.5144923 \\
(42.18)^{* * *}\end{array}$ \\
\hline $\operatorname{LLP}(-1)$ & $\begin{array}{c}0.474843 \\
(20.27)^{* * *}\end{array}$ & $\begin{array}{l}0.4719603 \\
(20.33)^{* * *}\end{array}$ & $\begin{array}{l}0.4644316 \\
(19.79)^{* * *}\end{array}$ & $\begin{array}{l}0.4637168 \\
(19.78)^{* * *}\end{array}$ & $\begin{array}{l}0.5261145 \\
(22.87)^{* * *}\end{array}$ \\
\hline Loan size (in log) & $\begin{array}{l}224,326.6 \\
(6.20)^{* * *}\end{array}$ & $\begin{array}{l}223,014.2 \\
(6.17)^{* * *}\end{array}$ & $\begin{array}{l}222,892.6 \\
(6.18)^{* * *}\end{array}$ & $\begin{array}{l}222,104.2 \\
(6.16)^{* * *}\end{array}$ & $\begin{array}{l}205,323.4 \\
(5.91)^{* * *}\end{array}$ \\
\hline EBTP & $\begin{array}{l}0.0971007 \\
(8.82)^{* * *}\end{array}$ & $\begin{array}{l}0.0981243 \\
(8.91)^{* * *}\end{array}$ & $\begin{array}{l}0.0990372 \\
(9.02)^{* * *}\end{array}$ & $\begin{array}{l}0.097572 \\
(8.90)^{* * *}\end{array}$ & $\begin{array}{c}-2.120169 \\
(-13.53)^{* * *}\end{array}$ \\
\hline $\begin{array}{c}\text { Loan size }(\text { in } \log ) \times \\
\text { EBTP }\end{array}$ & & & & & $\begin{array}{l}0.1135309 \\
(14.18)^{* * *}\end{array}$ \\
\hline Caa_Spread(-1) & $\begin{array}{c}-107,542.6 \\
(-1.11)\end{array}$ & & & & \\
\hline Caa_Spread(-2) & & $\begin{array}{c}32,993.31 \\
(0.35)\end{array}$ & & & \\
\hline Caa_Spread(-3) & & & $\begin{array}{l}294,032.2 \\
(3.11)^{* * *}\end{array}$ & & \\
\hline Caa_Spread(-4) & & & & $\begin{array}{l}338,348.7 \\
(3.54)^{* * *}\end{array}$ & $\begin{array}{l}264,720.9 \\
(2.87)^{* * *}\end{array}$ \\
\hline Obs. & 2,795 & 2,795 & 2,795 & 2,795 & 2,795 \\
\hline Banks & 215 & 215 & 215 & 215 & 215 \\
\hline Within group $\bar{R}^{2}$ & $53.33 \%$ & $53.31 \%$ & $53.48 \%$ & $53.54 \%$ & $56.90 \%$ \\
\hline Overall $\bar{R}^{2}$ & $95.77 \%$ & $95.81 \%$ & $95.81 \%$ & $95.80 \%$ & $96.55 \%$ \\
\hline Fixed Effect & Yes & Yes & Yes & Yes & Yes \\
\hline
\end{tabular}

Notes: LLP, NPL, Loan size, EBTP, and Caa Spread represent loan loss provision, non-performing loan, loan size in log, earnings before tax and provision, and credit spread. Numbers in parentheses are $t$-statistics. $* *$ represent significant at $1 \%$ significance level. 


\subsection{Forward-looking Provisioning of LLP}

Next we examine if LLP contains information for future bad loans. We first estimate four fixed-effect models (Model 1 to Model 4) of NPL on its own lag, lagged LLP, loan size in log, EBTP, and lagged high yield spread by one to four quarters for Model 1 to Model 4, respectively. We initially intend to include GDP growth in the models, but no significant result has been found, so we drop GDP growth from the equations. The reason using different orders of lagged bond yield spread for different models is because it reflects the expectation for possible future default by the market participants, and it is not appropriate to speculate the relationship between bond credit spread and NPL in the same period. Given the findings in Figure 1a, Model 1 to Model 4 use lagged high yield spread by one-to-four quarters, respectively. ${ }^{10}$

The results are reported in Table 3. Similar to the cases of LLP reported in Table 2, NPL is explained by its own lagged value to a large extent for the first four models. Second, overall LLP in the previous quarter has a positive and significant explanatory power for current NPL. This indicates when U.S. commercial bank managers determine the level of LLP, they do incorporate the information of their expectations for future bad loans.

For the first four models, contemporaneous loan size is shown to be positively related to NPL. This is intuitive because as the loan size gets larger, NPL can be larger accordingly. Contemporaneous earnings are also shown to be positively related to NPL, and the associated $t$-statistics are very large. This is counterintuitive because when the economy is in the periods of booms, earnings will be larger and NPL is expected to be relatively smaller. We speculate this phenomenon is possibly due to the fact that as the loan size becomes larger, earnings as well as NPL in absolute terms can also be larger simultaneously, resulting in a positive association between earnings and NPL. This argument can be supported by the observation of a large correlation coefficient between gross loan size and earnings, which is 0.813 . We thus add the interaction term of loan size and earnings as an additional independent variable into Model 4 to create a new model (Model 5). After adding this interaction term, the within group adjusted R-square is improved by more than $3 \%$, and the overall adjusted R-square is also somewhat improved. The partial effect of earnings on NPL becomes negative.

In sum, we have three major findings in the results of estimating NPL regressions. First, LLP has predictive power for NPL in next period after controlling the current level of NPL. This is the major finding of this study: when bank managers determine the level of LLP, they have incorporated the information of expected future bad loans.
Second, earnings in current period are negatively associated with NPL after controlling the effect of loan size. Finally, yield spread observed in the high yield corporate bond market also contains predictive information for future bad loans. This is in line with the results reported in figure $1 \mathrm{a}$.

\subsection{Additional Tests}

This section reports the results of empirical tests regarding if the level of LLR is smoothed by net loan charge-off and LLP, and if LLP provides clues for banks' future earnings according to the income signaling hypothesis.

\subsubsection{LLR Smoothing by Net Charge-off and LLP}

Income smoothing hypothesis asserts that bank managers have incentives to provision more in periods of boom and provision less in bad times. When LLP is recognized, it will reduce earnings and at the same time LLR is built up, which is used to offset future bad loans. Liu and Ryan (2006) argue that bank managers could attempt to obscure income-smoothing behavior by trying to minimize fluctuations in LLR to avoid regulatory and market scrutiny. This could be achieved through exercising discretion over loan charge-offs such as by accelerating charge-offs to offset higher loan loss provisions to keep loan loss reserves unchanged.

We examine how net loan charge-off ( $\mathrm{NCO}$ ), which is loan charge-off deducted by recoveries, is determined and whether LLR smoothing behavior by exercising discretion over NCO is present for U.S. commercial banks after the financial crisis. Liu and Ryan (2006) estimate the regression of recoveries on lagged gross loan charge-offs to test if loan charge-offs are determined to smooth LLR. We take an alternative approach and test if $\mathrm{NCO}$ is determined to smooth LLR by examining how NCO is related to LLP and LLR. First, if NCO is used to smooth LLR, it is likely NCO is positively associated with LLP. Second, from the perspective of time series, if LLR is a mean-reverting process, LLR will have a negative effect on the change in NCO when LLR is above its mean and a positive effect when LLR is below its mean. We estimate the regressions of NCO and report the results in table 4. 
Table 4. Net Charge-off Regressions

\begin{tabular}{|c|c|c|c|}
\hline \multicolumn{4}{|c|}{$\mathrm{NCO}$} \\
\hline Model & 1 & 2 & 3 \\
\hline Constant & $\begin{array}{c}-31,440.79 \\
(-1.16)\end{array}$ & $\begin{array}{c}-19,288.18 \\
(-0.68)\end{array}$ & $\begin{array}{l}-187,345.4 \\
(-5.87)^{* * *}\end{array}$ \\
\hline $\mathrm{NCO}(-1)$ & $\begin{array}{c}0.1280701 \\
(7.19)^{* * *}\end{array}$ & $\begin{array}{c}0.1286642 \\
(7.22)^{* * *}\end{array}$ & $\begin{array}{c}0.0666553 \\
(3.62)^{* * *}\end{array}$ \\
\hline LLP & $\begin{array}{l}0.8903968 \\
(21.14)^{* * *}\end{array}$ & $\begin{array}{l}0.8502208 \\
(17.17)^{* * *}\end{array}$ & $\begin{array}{c}0.66907 \\
(12.99)^{* * *}\end{array}$ \\
\hline EBTP & & $\begin{array}{c}-0.0356495 \\
(-1.54)\end{array}$ & $\begin{array}{l}-0.0938956 \\
(-4.03)^{* * *}\end{array}$ \\
\hline NPL & & & $\begin{array}{l}0.3251095 \\
(10.47)^{* * *}\end{array}$ \\
\hline D1 & $\begin{array}{l}141,215.4 \\
(4.10)^{* * *}\end{array}$ & $\begin{array}{c}140,433 \\
(4.08)^{* * *}\end{array}$ & $\begin{array}{l}131,530.5 \\
(3.90)^{* * *}\end{array}$ \\
\hline D2 & $\begin{array}{l}264,835.5 \\
(7.28)^{* * *}\end{array}$ & $\begin{array}{l}264,676.6 \\
(7.28)^{* * *}\end{array}$ & $\begin{array}{l}256,044.7 \\
(7.18)^{* * *}\end{array}$ \\
\hline D3 & $\begin{array}{c}374,474.3 \\
(10.36)^{* * * *}\end{array}$ & $\begin{array}{c}372,280.6 \\
(10.29)^{* * *}\end{array}$ & $\begin{array}{c}368,398.5 \\
(10.39)^{* * * *}\end{array}$ \\
\hline Obs. & 2,795 & 2,795 & 2,795 \\
\hline Banks & 215 & 215 & 215 \\
\hline Within group $\bar{R}^{2}$ & $20.54 \%$ & $20.61 \%$ & $23.85 \%$ \\
\hline Overall $\bar{R}^{2}$ & $71.59 \%$ & $69.77 \%$ & $76.57 \%$ \\
\hline Fixed effect & Yes & Yes & Yes \\
\hline
\end{tabular}

Notes: NCO, LLP, EBTP, and NPL represent net charge-off, loan loss provision, earnings before tax and provision, and non-performing loan. D1, D2 and D3 are dummies for second, third and fourth quarters, respectively. Numbers in parentheses are $t$-statistics. *** represent significant at $1 \%$ level.

Table 4 reports the estimation results of three regression equations. In Model 1, we regress $\mathrm{NCO}$ on its lagged value and LLP. Because there is a significant pattern that $\mathrm{NCO}$ is found to be smallest in the first quarter and largest in the fourth quarter. We add dummy variables into the model. D1 is 1 for second quarter and 0 otherwise. D2 and D3 are for third quarter and fourth quarter, respectively. Because NCO can be related to bank business conditions, we add earnings variable (EBTP) in Model 2 to capture the effect of business conditions. Furthermore, because NPL is a non-discretionary variable, it is likely that bank managers will determine a higher level of loan charge-off when NPL is higher. We add NPL in Model 3. From the results in Table 4, we can observe that LLP is the most important determinant for NCO, although NPL also has a significant explanatory power. This indicates $\mathrm{NCO}$ is positively associated with LLP, and we thus can't rule out the possibility of LLR smoothing by exercising discretion over loan charge-offs.

Second, we adapt the spirit of a mean-reverting time series process to examine if NCO is used to smooth LLR. If a time series is governed by a mean-reverting process, change in time series in current period will be adjusted by its level relative to its own long-run mean in the last period. Similarly, if LLR is governed by a mean-reverting process, and bank managers tend to smooth the level of LLR by determining a higher level of NCO when LLR is higher and a lower level of NCO when LLR is low, the level of LLR relative to its mean (referred to as the "error-correction term") in the last period will affect the change in $\mathrm{NCO}$ in current period. We thus formulate the model as follows:

$$
\Delta \mathrm{NCO}_{i, t}=\beta_{0}+\lambda\left(\delta-L L R_{i, t-1}\right)+u_{i, t},
$$

where $\Delta \mathrm{NCO}_{i, t}$ is the change in NCO for bank $i$ at time $t, \lambda$ is mean-reversion parameter, $\delta$ is long-run mean of LLR, $\beta_{0}$ is a constant, and $u_{i, t}$ is error term.

The estimations of regressions of change in LLR and change in NCO are illustrated in Table 5. Each model contains the error-correction term. For Model 1, when change in LLR is regressed on its own deviation from mean in the last period, the coefficient of LLR's error-correction term is positive and very significant. A positive coefficient indicates that when LLR is below (above) its mean, change in next period will tend to increase (decrease). This is consistent with the phenomenon observed for a typical mean-reverting process. For Model 2, when change in $\mathrm{NCO}$ is regressed on LLR's error-correction term in last period, the coefficient $(\lambda)$ of LLR's error-correction term is also positive and significant. A positive $\lambda$ is inconsistent with the hypothesis that NCO is used to smooth LLR. Because under the hypothesis that NCO is used to smooth LLR, when LLR in the last period is relatively low (a positive error correction term), current change in $\mathrm{NCO}$ should be smaller to keep LLR higher. When we incorporate current LLP in Model 3, we find that the coefficient of LLR's deviation from its mean in last period is still positive but only marginally significant. LLP is shown to be the most dominant explanatory variable for 
contemporaneous change in NCO. Combining the results from Tables 4 and 5, although NCO is positively associated with LLP and NPL, and negatively associated with earnings, $\mathrm{NCO}$ is not used to smooth LLR as argued by Liu and Ryan (2006) for U.S. commercial banks during the post-crisis period.

In table 2, we have identified several determinants for LLP. LLP is known to be an expense in banks' income statements and can be determined to manage reported earnings. As mentioned earlier, Liu and Ryan (2006) argue that bank managers could attempt to obscure income-smoothing behavior by trying to minimize fluctuations in LLR to avoid regulatory and market scrutiny. We raise another question: does the determination of LLP also reflect the information of the relative level in LLR? We test this hypothesis by re-estimating Model 6 of Table 2 but with the significant independent variables only and the incorporation of LLR's error-correction term in last period. If LLP is also determined to smooth LLR, we expect the effect of LLR's error-correction term to be positive. The results are reported in Table 6 , which indicate

LLR's error-correction term in last period does has a positive and significant effect on current LLP, supporting the hypothesis that LLP is used to smooth LLR.

Table 5. Regressions of changes in loan loss reserve and net charge-off on mean deviation of LLR

\begin{tabular}{|c|c|c|c|}
\hline Model & 1 & 2 & 3 \\
\hline Dependent Variable & $\Delta \mathrm{LLR}$ & $\triangle \mathrm{NCO}$ & $\triangle \mathrm{NCO}$ \\
\hline \multirow[t]{2}{*}{ Constant } & 549.1759 & $1,913.217$ & $-65,726.52$ \\
\hline & $(2.10)^{* *}$ & $(0.11)$ & $(-3.52)^{* * *}$ \\
\hline$(23,441.23-\operatorname{LLR}(-1))$ & 0.2926015 & 5.099963 & 1.67244 \\
\hline \multirow[t]{2}{*}{ LLP } & & & 0.6578676 \\
\hline & & & $(10.19)^{* * *}$ \\
\hline Obs. & 2,795 & 2,795 & 2,795 \\
\hline Banks & 215 & 215 & 215 \\
\hline Within group $\bar{R}^{2}$ & $18.16 \%$ & $1.43 \%$ & $5.25 \%$ \\
\hline Overall $\bar{R}^{2}$ & $0.12 \%$ & $0.02 \%$ & $3.90 \%$ \\
\hline Fixed Effect & Yes & Yes & Yes \\
\hline
\end{tabular}

Notes: $\triangle \mathrm{LLR}, \triangle \mathrm{NCO}$ and LLP represent changes in loan loss reserve, net charge-off and loan loss provision. The error-correction term $\left(23,441.23-\mathrm{LLR}_{t-1}\right)$ is the deviation of LLR from its mean value. Numbers in parentheses are $t$-statistics. $* * *, * *, *$ represent significant at $1 \%$, $5 \%$ and $10 \%$ significance levels, respectively.

Table 6. LLR smoothing: Regression of LLP on LLR's mean deviation

\begin{tabular}{|c|c|c|c|c|c|c|}
\hline Dependent variable: LLP & & & & & & \\
\hline Independent variable & Constant & LLP(-1) & NPL & EBTP & Caa_Spread & $(23,441.23-$ LLR $(-1))$ \\
\hline Coefficient & $-60,389.91$ & 0.5410298 & 0.145556 & -0.0861559 & $206,696.6$ & 4.161329 \\
\hline$t$-Statistic & $(-6.07)^{* * *}$ & $(38.36)^{* * *}$ & $(16.37)^{* * *}$ & $(-14.01)^{* * *}$ & $(2.79)^{* * *}$ & $(24.00)^{* * *}$ \\
\hline Obs. 2,795 & & & & & & \\
\hline Banks 215 & & & & & & \\
\hline Within group $\bar{R}^{2}$ & $68.93 \%$ & & & & & \\
\hline Overall $\bar{R}^{2}$ & $67.43 \%$ & & & & & \\
\hline Fixed effect & Yes & & & & & \\
\hline
\end{tabular}

Notes: LLP, NPL, EBTP, and Caa_Spread represent loan loss provision non-performing loan, earnings before tax and provision and credit spread. The error-correction term $\left(23,441.23-\operatorname{LLR}_{t-1}\right)$ is the deviation of LLR from its mean value. Numbers in parentheses are $t$-statistics. *** represent significant at $1 \%$ level. 
Table 7. Income signaling hypothesis test: Regression of earnings before tax and provision

\begin{tabular}{|c|c|c|c|c|}
\hline Dependent variable: EBTP & & & & \\
\hline Independent variable & Constant & EBTP(-1) & EBTP(-1) & $\Delta$ GDP \\
\hline Coefficient & $280,317.6$ & 0.0134965 & -1.023796 & 296.4113 \\
\hline$t$-Statistic & $(12.57)^{* * *}$ & $(0.69)$ & $(-24.41)^{* * *}$ & $(2.24)^{* *}$ \\
\hline Obs. 2,795 & & & & \\
\hline Banks 215 & & & & \\
\hline Within group $\bar{R}^{2}$ & $24.38 \%$ & & & \\
\hline Overall $\bar{R}^{2}$ & $22.21 \%$ & & & \\
\hline
\end{tabular}

Notes: EBTP, LLP, and $\triangle G D P_{t}$ represent earnings before tax and provision, loan loss provision, and GDP growth rate. Numbers in parentheses are $t$-statistics. ${ }^{* * *}$ and $* *$ represent significant at $1 \%$ and $5 \%$ significance levels, respectively.

Table 8. Signaling hypothesis test: Regression of earning before tax and provision

\begin{tabular}{|c|c|c|c|c|}
\hline \multicolumn{5}{|l|}{ Dependent vaiable: EBTP } \\
\hline Independent variable & Constant & EBTP(-1) & $\operatorname{LLP}(-1)$ & $\Delta \mathrm{GDP}$ \\
\hline Coefficient & $280,317.60$ & 0.0134965 & 1.023796 & 296.4113 \\
\hline t-Statistic & $(12.57)^{* * *}$ & -0.69 & $(-24.41)^{* * *}$ & $(2.24)^{* *}$ \\
\hline Obs. & 2,795 & & & \\
\hline Banks & 215 & & & \\
\hline Within group $\bar{R}^{2}$ & $24.38 \%$ & & & \\
\hline Overall $\bar{R}^{2}$ & $22.21 \%$ & & & \\
\hline Fixed effect & Yes & & & \\
\hline
\end{tabular}

Notes: EBTP, LLP, and $\triangle G D P_{t}$ represent earning before tax and provision, loan loss provision, and GDP growth rate. Numbers in parentheses are $t$-statistics. ${ }^{* *}$ and ${ }^{* *}$ represent significant at $1 \%$ and $5 \%$ significance levels, respectively.

\subsubsection{Income Signaling Hypothesis}

Finally we investigate if income signaling hypothesis holds for U.S. commercial banks in the post-financial crisis period. Signaling hypothesis asserts changes in LLP have explanatory power for future earnings. An increase in LLP is regarded as a sign of strength by investors. We test this hypothesis by estimating the following regression:

$$
\begin{gathered}
\operatorname{EBTP}_{i, t}=\beta_{0}+\beta_{1} \operatorname{EBTP}_{i, t-1}+\beta_{2} L L P_{i, t-1}+\beta_{3} \Delta G D P_{t}+ \\
u_{i, t}
\end{gathered}
$$

The results are reported in Table 7.

The results of Table 8 show that earnings in current period have no predictive power for earnings in next quarter. The coefficient of LLP is negative and significant, inconsistent with income signaling hypothesis. Finally, GDP growth has a positive and significant effect on banks' earnings, consistent with our expectation.

\section{Concluding Remarks}

Loan loss provisions are determined by bank manager's discretion. This paper investigates the information contents of loan loss provisions of the U.S. commercial banks after the financial crisis. This paper adapts a time series framework concerning the information processes of loan loss provision and NPL. Empirically, we find that loan loss provision does contain predictive information for future NPL. This is consistent with the argument of Bushman and Williams (2012) in which forward-looking provisioning reflecting timely recognition of expected future loan losses is associated with enhanced risk-taking discipline. Another major finding of this paper is that corporate bond spread contains information for future NPL, and the levels of loan loss provisions determined by bank managers are positively associated with corporate bond spread.

Previous literature in the area of loan loss reserves and provisions focus on income-smoothing hypothesis, capital management and income signaling hypothesis. This study also re-tests these hypotheses. We find that the traditional hypotheses of income-smoothing or earnings management, capital management and income signaling hypotheses are not supported by our data. In particular, our finding that earnings and loan loss provisions are negatively correlated indicates the strengthening of the incurred loss model for loan loss provisioning. Finally, loan loss provision determination also helps smooth loan loss reserves in the long run. That is, when exercising the discretion of loan loss provisions, smoothing the long-run level of loan loss reserves has been considered. 


\section{Appendix A}

See Table A1.

Table A1. The definitions of bank variables

\begin{tabular}{|c|c|}
\hline $\begin{array}{l}\text { Loan Loss Reserves } \\
\text { (LLR) }\end{array}$ & $\begin{array}{l}\text { Loan loss reserve is a contra-asset account in the balance sheet, which reflects the portion of loan principal not } \\
\text { expected to be paid back. Loan loss reserves also called allowance for loan losses or reserves for credit losses } \\
\text { (Walter, 1991) : } \\
\text { LLR = loan loss provisions + lagaed loan loss reserves - (loan charge - offs) (Lepetit et al. 2012) }\end{array}$ \\
\hline $\begin{array}{l}\text { Loan Loss } \\
\text { Provisions (LLP) }\end{array}$ & $\begin{array}{l}\text { Loan loss provisions, an income statement expense account showing amount added to loan loss reserves (Walter, } \\
1991 \text { ). }\end{array}$ \\
\hline $\begin{array}{l}\text { Non-performing } \\
\text { Loan (NPL) }\end{array}$ & $\begin{array}{l}\text { NPL commonly described as loans in arrears for at least } 90 \text { days, have been widely used as a judgment of the asset } \\
\text { quality among lending institutions as banks and are often associated with failures and financial crises in both } \\
\text { developed and developing countries. }\end{array}$ \\
\hline Charge-off & $\begin{array}{l}\text { Completely removing a loan from the balance sheet by subtracting its book value from loans and from loan loss } \\
\text { reserves, also called write-off (Walter, 1991). }\end{array}$ \\
\hline Recovery & Funds received on a loan previously charged off (Walter, 1991). \\
\hline $\begin{array}{l}\text { Net } \\
\text { (NCO) }\end{array}$ & $\begin{array}{l}\text { Net charge-offs are deducted from loan loss reserves, which formed then part of primary capital (Lepetit et al., } \\
\text { 2012): (Gross)Charge - off }- \text { Recovery }=\text { Net charge }- \text { off }\end{array}$ \\
\hline Gross loan & Gross loan $=$ Net loan + Non - performing loan \\
\hline EBTP & $\begin{array}{l}\text { Earnings before tax and provision, this is the item to check if the earnings is one of the element to determine the } \\
\text { loan loss provision or not: } E B T P=\text { Earning }+ \text { tax }+ \text { provision }\end{array}$ \\
\hline Capital & Tier I regulatory capital ratio $(\%)$ \\
\hline
\end{tabular}

\section{REFERENCES}

[1] Ahmed, Anwer S., Carolyn Takeda, and Shawn Thomas, 1999, Bank loan loss provisions: a reexamination of capital management, earnings management and signaling effects, Journal of Accounting and Economics 28, pp. 1-25.

[2] Angbazo, L.A., Mei, J.and Saunders, A.,1998, Credit spreads in the market for highly leveraged transaction loans, Journal of Banking \& Finance 22,pp.1249-1282

[3] Bangia, A., Diebold, F.X., Kronimus, A., Schagen, C., Schuermann, T., 2002. Ratings migration and the business cycle, with application to credit portfolio stress testing. Journal of Banking and Finance 26, pp.445-474.

[4] Balla, E. and Ross, M.J., 2011, Loan loss reserves, accounting constraints, and bank ownership structure, the Federal Reserve Bank of Richmond, No.11-09.

[5] Beatty, A., Chamberlain, S., Magliolo, J., 1995. Managing financial reports of commercial banks: the influence of taxes, regulatory capital and earnings. Journal of Accounting Research 27, 157-178.

[6] Beatty, A., Liao, S., 2011. Do delay in expected loss recognition affects banks' willingness to lend? Journal of Accounting and Economics 52, 1-20.

[7] Beaver, WH, Eger, C, Ryan, S \& Wolfson, M 1989, „Financial Reporting, Supplemental Disclosures, and Bank Share Prices ${ }^{\text {ee }}$, Journal of Accounting Research, vol.27, no. 2, pp. 157-178.

[8] Beaver, WH., Engel, E.E., 1996,Discretionary behavior with respect to allowances for loan losses and the behavior of security prices, Journal of Accounting and Economics 22 ,pp.177-206
[9] Bella, Eliana and Andrew McKenna, 2009, Dynamic provisioning: a countercyclical tool for loan loss reserves, Economic Quarterly, Vol. 95, pp.383-418.

[10] Bella, Eliana, Morgan J. Ross, and Jessie Romero, 2012, Loan loss reserve accounting and bank behavior, Economic Brief, March, the Federal Reserve Bank of Richmond, EB12-03, pp. 1-4.

[11] Bikker, J.A., P. A. J. Metzemakers, 2005. Bank provisioning behavior and procyclicality, Journal of International Financial Markets, Institutions, and Money 15, pp.141-157.

[12] Bouvatier, Vincent, and Laetitia Lepetit, 2008. Banks' procyclical behavior: does provisioning matter? Journal of Financial Markets, Institutions, and Money 18 (December), pp. 513-526.

[13] Bushman, R.M. and C.D. Williams, 2012. Accounting discretion, loan loss provisioning, and discipline of Banks' risk-taking, Journal of Accounting and Economics 54, pp. $1-18$.

[14] Collins, J., D. Shackelford, and J. Wahlen, 1995. Bank differences in the coordination of regulatory capital, earnings and taxes, Journal of Accounting Research 33 (2), pp.263-292.

[15] Cornett, M.M., Marcus, A.J., Tehranian, H., 2008. Corporate governance and pay-for-performance: the impact of earnings management. Journal of Financial Economics 87, 357-373.

[16] Elton, E.J., Gruber, M.J., Agrawal, D., Mann, D., 2001. Explaining the rate spread on corporate bonds. Journal of Finance 56, pp.247-277. Fuller, W.A., 1976. Introduction to statistical time series, Wiley, New York, New York, U.S.A.

[17] Fonseca, A.R., González, F., 2008,Cross-country determinants of bank income smoothing by managing loan-loss provisions, Journal of Banking \& Finance 
32,pp. $217-228$

[18] Fuller, W.A., Introduction to Statistical Time Series, 1976 (Wiley: New York).

[19] Gambera, M., 2000. Simple forecasts of bank loan quality in the business cycle. Working Paper, Federal Reserve Bank of Chicago, Supervision and Regulation Department, Emerging Issues Series, Chicago: S\&R-2000-3.

[20] Greenawalt, M. B., Sinkey Jr., J.F., 1988. Bank loss provisions and the income-smoothing hypotheses: an empirical analysis, 1976-1984. Journal of Financial Services Research 1, pp. 301-318.

[21] Hasan, Iftekhar and Larry D. Wall, 2004. Determinants of the loan loss allowance: some cross-country comparisons, The Financial Review 39, pp. 129-152.

[22] Jiang, Xiaoquan and Bong-Soo Lee, 2013. Equity issues and aggregate market returns under information asymmetry, Quantitative Finance, Vol.13, pp. 281-300.

[23] Laeven, Luc, and Giovanni Majnoni, 2003. Loan loss provisioning and Economic slowdowns: too much, too late? Journal of Financial Intermediation 12 (April), pp. 178-197.

[24] Lepetit, Laetitia, Frank Strobel, and David G. Dickinson, 2012. Does Uncertainty Matter for Loan Charge-offs? Journal of International Financial Markets, Institutions \& Money, pp.264-277.

[25] Liu, Chi-Chun, and Stephen G. Ryan, 2006. Income Smoothing over the Business Cycle: Changes in Banks' Coordinated Management of Provisions for Loan Losses and Loan Charge-Offs from the Pre-1990 Bust to the 1990s Boom. Accounting Review 81, pp.421-441.

[26] Longstaff, F. A., and E. S. Schwartz, 1995. A Simple Approach to Valuing Risky Fixed and Floating Rate Debt, Journal of Finance 50, 789-819.

[27] Merton, R., 1977. An analytical derivation of the cost of deposit insurance and loan guarantees. Journal of Banking and Finance 1, pp.3-11.

[28] Moyer, S., 1990. Capital adequacy ratio regulations and accounting choices in commercial banks. Journal of Accounting and Economics 13 (2), pp.123-154.

[29] Nickell, P., Perraudin, W. Varotto, S., 2000. Stability of rating transitions. Journal of Banking and Finance 24, pp. 203-227.

[30] Norden, L. and W. Wagner, 2008. Credit derivatives and loan pricing, Journal of banking and finance 32 2560-2569.

[31] Sims, Christopher, A., 1972. Money, income and causality, American Economic Review 62 (4), pp.540-552.

[32] Thomas, H., Wang, Z.,2004, The integration of bank syndicated loan and junk bond markets, Journal of Banking \& Finance 28 ,pp.299-329

[33] Wahlen, J., 1994. The nature of information in commercial bank loan loss disclosures, Accounting Review 69 (3), pp. 455-478.

[34] Wall, Larry D., and Timothy W. Koch, 2000. Bank loan loss accounting: a review of theoretical and empirical evidence. Federal Reserve Bank of Atlanta Economic Review Q2, pp. 1-20.

[35] Walter, John R., Loan Loss Reserves, 1991. FRB Richmond Economic Review 77, pp.20-30. 